\title{
Public Social Expenditures and Economic Growth: Evidence from Selected OECD Countries
}

\author{
F. Ozlem Alper ${ }^{1} \&$ Mehmet Demiral $^{1}$ \\ ${ }^{1}$ Department of Economics, Faculty of Economics and Administrative Sciences, Omer Halisdemir University, Nigde, \\ Turkey \\ Correspondence: Mehmet Demiral, Omer Halisdemir University, Department of Economics, Faculty of Economics, \\ and Administrative Sciences, 2/205, 51240-Nigde, Turkey.
}

Received: December 5, 2016

Accepted: December 12, 2016

Online Published: December 14, 2016

doi:10.5430/rwe.v7n2p44

URL: http://dx.doi.org/10.5430/rwe.v7n2p44

\begin{abstract}
There is a longstanding debate on whether the government expenditures contribute to economic growth. The endogenous growth theories, in general, predict that effective public expenditures can lead to increases in economic growth trends of countries regardless of their development stages or income levels. Starting from this prediction, this study aims to investigate the effects of governments' social expenditure proxies namely education, health and social spending on economic growth performances presented by the changes in the gross domestic product (GDP) per capita. Using the feasible generalized least squares (FGLS) estimators based on a balanced panel dataset covering 2002-2013 periods of 18 OECD countries, the study concludes that social expenditures in all three dimensions significantly contribute to the economic growth. Overall results underline that public expenditures can be productive as an investment in the case of selected OECD countries.
\end{abstract}

Keywords: economic growth, feasible generalized least squares, OECD countries, social expenditure

\section{Introduction}

Both economists and policymakers acknowledge economic growth as one of the most important indicators of welfare level in a country. Therefore, increasing the income level is the main concern of public policies. Studies in the related immense literature on the determinants of economic growth have commonly examined the effects of economic factors like capital and labor stocks, financial development, investment, productivity, level of production technology, trade, etc. (Domar, 1946; Solow, 1956; Barro, 1991; Mankiw, 1995; Barro, 2001; Bassanini and Scarpetta, 2002; Hausmann, Pritchett, and Rodrik, 2005).

Until the endogenous growth theories, the traditional neoclassic approach which underlined that the macroeconomic policies of the government is not effective on the economic growth dominated the growth literature. On the contrary, the endogenous growth models take government expenditures in health, education, social security and even in defense areas into account while modeling the growth of countries. The origins of endogenous growth models are based on the studies of Romer (1986), Lucas (1988), Barro (1990) and Rebelo (1991). Determining the economic growth as endogenous means that government can affect the economic growth rate by applying macroeconomic policies. In other words, government affects long-term growth with taxing, spending and changing the budget balance (Pevcin, 2004). However, the endogenous growth models have focused on the role of human capital as a key driver of economic growth (Stokey, 1991; Pyo, 1995) which directs the public expenditures to invest in the human capital stock.

The combination of the expenditures on human capital also matters in the endogenous growth models that there are important and direct relations between the government expenditures like education, health, social protection and social security and economic growth. Education is one of the most important factors which contributes to the sustainable economic growth and competitiveness of the countries. Therefore, it is expected that education expenditures contribute to the economic growth by increasing the efficiency and productivity levels of individuals (Afzal et al., 2010).

Health expenditures have multiple contributions to economic growth in both the short-run and long-run. Healthy workers become more productive while ill workers become less productive and tend to be absent in workplace or work inefficiently. Moreover, healthy children, possible workers in the future, can affect the income trajectories of countries (Bloom and Canning, 2000; Lusting, 2006; Barro, 2013). 
Another important content of public expenditures within especially the social government program is social protection expenditures consist of health, insurance, and pension payments along with social services and aids (Adema, Fron and Ladaique, 2011). However, the effects of social protection expenditures of governments on long-run economic growth are not clear with two opposite evidence. On the one hand, the benefit these programs provide can discourage people from working. Because of the decline in the amount of labor supplied in the economy, the level of output and, in some circumstances, the level of capital investment and hence growth can lower. On the other hand, social protection expenditures will make a positive contribution to the economic growth since the individuals are insured against disease and unemployment risk and therefore they become more productive and motivated to work (Arjona, Ladaique and Pearson, 2002). These two different suggestions keep the doors open to the debates about whether social protection is an expenditure or an investment.

Starting from the predictions of endogenous growth models, this study aims to empirically test the effects of governments' expenditures in social areas like education, health, and social protection which also embodies social security on economic growth for selected 18 OECD countries. The rest of the study is organized as follows: In section 2 we present growth trends and social expenditures in selected OECD countries, followed by the literature review in section 3. After model, data, and method are introduced in section 4, we report empirical results in section 5. Finally, the study concludes with some discussions of findings in the last section.

\section{Growth Trends and Social Expenditures in OECD Countries}

The recent turning point in global growth trends was the 2008-2009 crisis initially started in the finance sector of the United States and then spread to the real sector. This crisis not only affected the United States but also affected the whole world economy fast with striking decreases of growth rates as shown in Table 1 presenting the OECD countries case. As the crisis deepened, the importance of social protection and social security programs well-understood and increased.

It is seen from the Table 1 that the countries especially Czech Republic, Estonia, and Turkey, recorded high growth rates before the crisis. Sharp declines in 2008 and 2009 in selected OECD countries reveal how deep and pervasive the recession was. Moreover, during the post-crisis period, most of the countries seem to be having problems in catching the same growth performances of the pre-crises periods.

Table 1. Percentage changes in gross domestic products (expenditure approach), 2002-2015

\begin{tabular}{|c|c|c|c|c|c|c|c|c|c|c|c|c|c|c|}
\hline Countries & 2002 & 2003 & 2004 & 2005 & 2006 & 2007 & 2008 & 2009 & 2010 & 2011 & 2012 & 2013 & 2014 & 2015 \\
\hline Austria & 1.7 & .8 & 2.7 & 2.1 & 3.4 & 3.6 & 1.5 & -3.8 & 1.9 & 2.8 & .7 & .1 & .6 & 1.0 \\
\hline Belgium & 1.8 & .8 & 3.6 & 2.1 & 2.5 & 3.4 & .7 & -2.3 & 2.7 & 1.8 & .1 & -.1 & 1.7 & 1.5 \\
\hline Canada & 3.0 & 1.8 & 3.1 & 3.2 & 2.6 & 2.1 & 1.0 & -2.9 & 3.1 & 3.1 & 1.7 & 2.2 & 2.5 & 1.1 \\
\hline Czech Republic & 1.6 & 3.6 & 4.9 & 6.4 & 6.9 & 5.5 & 2.7 & -4.8 & 2.3 & 2.0 & -.8 & -.5 & 2.7 & 4.5 \\
\hline Denmark & .5 & .4 & 2.7 & 2.3 & 3.9 & .9 & -.5 & -4.9 & 1.9 & 1.3 & .2 & .9 & 1.7 & 1.6 \\
\hline Estonia & 6.1 & 7.4 & 6.3 & 9.4 & 1.3 & 7.7 & -5.4 & -14.7 & 2.3 & 7.6 & 4.3 & 1.4 & 2.8 & 1.4 \\
\hline Finland & 1.7 & 2.0 & 3.9 & 2.8 & 4.1 & 5.2 & .7 & -8.3 & 3.0 & 2.6 & -1.4 & -.8 & -.7 & .2 \\
\hline France & 1.1 & .8 & 2.8 & 1.6 & 2.4 & 2.4 & .2 & -2.9 & 2.0 & 2.1 & .2 & .6 & .6 & 1.3 \\
\hline Germany & .0 & -.7 & 1.2 & .7 & 3.7 & 3.3 & 1.1 & -5.6 & 4.1 & 3.7 & .5 & .5 & 1.6 & 1.7 \\
\hline Italy & .2 & .2 & 1.6 & .9 & 2.0 & 1.5 & -1.1 & -5.5 & 1.7 & .6 & -2.8 & -1.7 & .1 & .7 \\
\hline Netherlands & .1 & .3 & 2.0 & 2.2 & 3.5 & 3.7 & 1.7 & -3.8 & 1.4 & 1.7 & -1.1 & -.2 & 1.4 & 2.0 \\
\hline Norway & 1.4 & .9 & 4.0 & 2.6 & 2.4 & 2.9 & .4 & -1.6 & .6 & 1.0 & 2.7 & 1.0 & 1.9 & 1.6 \\
\hline Portugal & .8 & -.9 & 1.8 & .8 & 1.6 & 2.5 & .2 & -3.0 & 1.9 & -1.8 & -4.0 & -1.1 & .9 & 1.6 \\
\hline Spain & 2.9 & 3.2 & 3.2 & 3.7 & 4.2 & 3.8 & 1.1 & -3.6 & .0 & -1.0 & -2.9 & -1.7 & 1.4 & 3.2 \\
\hline Sweden & 2.1 & 2.4 & 4.3 & 2.8 & 4.7 & 3.4 & -.6 & -5.2 & 6.0 & 2.7 & -.3 & 1.2 & 2.6 & 4.1 \\
\hline Turkey & 6.2 & 5.3 & 9.4 & 8.4 & 6.9 & 4.7 & .7 & -4.8 & 9.2 & 8.8 & 2.1 & 4.2 & 2.9 & 4.0 \\
\hline United Kingdom & 2.4 & 3.5 & 2.5 & 3.0 & 2.5 & 2.6 & -.6 & -4.3 & 1.9 & 1.5 & 1.3 & 1.9 & 3.1 & 2.2 \\
\hline United States & 1.8 & 2.8 & 3.8 & 3.3 & 2.7 & 1.8 & -.3 & -2.8 & 2.5 & 1.6 & 2.2 & 1.7 & 2.4 & 2.6 \\
\hline European Union (28) & 1.3 & 1.4 & 2.5 & 2.1 & 3.3 & 3.0 & .4 & -4.4 & 2.1 & 1.7 & -.5 & .2 & 1.5 & 2.2 \\
\hline European Union (15) & 1.2 & 1.2 & 2.4 & 1.9 & 3.1 & 2.8 & .2 & -4.4 & 2.1 & 1.5 & -.6 & .1 & 1.5 & 2.1 \\
\hline OECD-Total & 1.7 & 2.1 & 3.3 & 2.8 & 3.1 & 2.7 & .2 & -3.5 & 3.0 & 1.9 & 1.3 & 1.3 & 1.9 & 2.2 \\
\hline
\end{tabular}

Source: OECD (2016). 
As seen in Table 2, even the growth rates decreased in the post-crises period, the shares of public social expenditures in GDP has increased which is seen consistent with the argument suggesting that countries need to spend and invest more in social programs to ease and relieve the negative outcomes of the market failures resulted in crises.

Table 2. Public social expenditures, aggregated, percentages of gross domestic products, 2002-2015

\begin{tabular}{|c|c|c|c|c|c|c|c|c|c|c|c|c|c|c|}
\hline 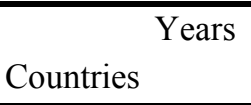 & 2 & 33 & 44 & 95 & 96 & 97 & 98 & 09 & 10 & 11 & 12 & 2013 & 14 & 201 \\
\hline Austria & & 26.5 & & 5.9 & 7 & 25.1 & 25.6 & .5 & .6 & 8 & 27.2 & 27.6 & 27.9 & 28.0 \\
\hline & 24.4 & & .3 & .3 & 2 & 24.9 & 26.3 & .6 & 3 & 28.7 & 29.0 & 29.3 & 9.2 & 29. \\
\hline & & 6.3 & 5.3 & .1 & & 2 & .3 & .1 & & 1 & 1 & 6.9 & 8 & 17.2 \\
\hline & 18.7 & 18.8 & 8.0 & .1 & 17.8 & 17.6 & 17.8 & 20.2 & 19.8 & 19.8 & 20.0 & 20.3 & 19.9 & 19.5 \\
\hline & & 5.3 & 5.1 & .2 & 25.0 & 25.0 & 5.4 & 8.3 & .9 & 28.9 & 28.9 & 9.0 & 9.0 & 8.8 \\
\hline & 8 & 12.9 & 3.4 & 3.0 & 12.6 & 12.6 & 15.4 & 19.6 & 18.3 & 16.3 & 15.9 & 15.9 & 16.0 & 17.0 \\
\hline & 2 & 23.8 & 4.0 & 3.9 & 23.8 & 22.9 & 23.3 & 26.9 & 27.4 & 27.1 & 28.4 & 29.5 & 30.2 & 30.6 \\
\hline & .2 & 8.6 & 3.7 & 3.7 & 28.1 & 28.0 & 28.2 & .5 & 30.7 & 30.5 & 31.0 & 5 & 31.9 & 31.7 \\
\hline & .1 & 26.6 & 6.0 & 26.3 & 25.0 & 24.1 & 24.2 & 26.7 & 25.9 & 24.7 & 24.6 & 4.8 & 24.9 & 25.0 \\
\hline Itc & & 3.6 & .9 & 4.1 & 24.2 & 24.7 & 25.6 & 27.7 & 27.6 & 27.3 & 28.1 & 8.6 & 9.0 & 28.9 \\
\hline Neth & .2 & 20.0 & 9.9 & 20.5 & 20.2 & 19.9 & 19.6 & 21.6 & 22.1 & 22.0 & 22.5 & 22.9 & 22.7 & 22.3 \\
\hline & & .7 & 2.3 & 0.7 & 19 & 19.6 & 19.2 & 2.3 & 21.9 & 21.4 & 21.3 & 21.8 & 2.4 & 23.9 \\
\hline Por & .3 & 21.4 & 21.7 & 22.3 & 22.1 & 21.8 & 22.2 & 24.6 & 24.5 & 24.4 & 24.5 & 5.5 & 24.5 & 24.1 \\
\hline Spa & & 19.9 & 20.1 & 20.4 & 20.4 & 20.8 & 22.2 & 25.4 & 25.8 & 26.3 & 26.1 & 26.3 & 26.1 & 25.4 \\
\hline & 27.6 & 28.2 & 27.7 & 27.4 & 26.6 & 25.5 & 25.6 & 27.7 & 26.3 & 25.8 & 26.7 & 27.4 & 27.1 & 26.7 \\
\hline Turkey & 9.0 & 10.0 & 10.4 & 10.3 & 10.3 & 11.1 & 11.6 & 13.5 & 12.8 & 12.5 & 13.0 & 13.4 & 13.5 & -- \\
\hline & 18.6 & 19.0 & 9.5 & 19.4 & 19.2 & 19.5 & 20.9 & 23.0 & 22.8 & 22.4 & 22.5 & 21.9 & 21.6 & 21.5 \\
\hline & 15.7 & 15.9 & 15.8 & 15.6 & 15.7 & 15.8 & 16.5 & 18.6 & 19.3 & 19.1 & 18.8 & 18.8 & 18.8 & 19.0 \\
\hline OECD - Total & 18.7 & 19.0 & 18.8 & 18.8 & 18.5 & 18.3 & 19.0 & 21.2 & 21.1 & 20.7 & 21.0 & 21.1 & 21.1 & 21.0 \\
\hline
\end{tabular}

Notes: Aggregated public social expenditures comprise of main social policy areas like old age, survivors, incapacity-related benefits, health, family, active labor market programs, unemployment, housing, and other social policy areas. All these benefits can be both cash and non-cash (benefits-in-kind). See Adema et al., (2011) for more details on the methodology and analytical explanations.

Source: OECD (2016).

\section{Literature Review}

There are many empirical studies investigating the relationships between the public expenditure combinations and economic growth in both developing and developed countries. Even the immense interests in the current literature on the relationship, the conclusions for the impacts of social expenditures on the growth is not that clear. This ambiguity seems to be caused by differences in the methods, samples, and time spans in the studies. Some selected studies with different findings are reviewed and summarized in Table 3.

Table 3. Selected studies with different findings in the literature

\begin{tabular}{cccccc}
\hline $\begin{array}{c}\text { Author(s) } \\
\text { (Year) }\end{array}$ & $\begin{array}{c}\text { Country } \\
\text { Sample }\end{array}$ & Period & Variables & Method & Findings \\
\hline $\begin{array}{c}\text { Landau } \\
(1983)\end{array}$ & $\begin{array}{c}104 \\
\text { developing } \\
\text { and }\end{array}$ & $1961-1976$ & $\begin{array}{c}\text { GDP per capita; } \\
\text { public expenditures; } \\
\text { total education }\end{array}$ & $\begin{array}{c}\text { Comparative } \\
\text { country analysis } \\
\text { based on the }\end{array}$ & $\begin{array}{c}\text { Negative relationship } \\
\text { between the growth } \\
\text { rate of GDP per capita } \\
\text { and the share of }\end{array}$ \\
\hline
\end{tabular}




\begin{tabular}{|c|c|c|c|c|c|}
\hline & $\begin{array}{l}\text { developed } \\
\text { countries) }\end{array}$ & & investments & $\begin{array}{l}\text { traditional } \\
\text { methods }\end{array}$ & $\begin{array}{l}\text { government } \\
\text { consumption } \\
\text { expenditures }\end{array}$ \\
\hline $\begin{array}{l}\text { Baum and } \\
\text { Lin } \\
\text { (1993) }\end{array}$ & $\begin{array}{c}58 \\
\text { (developing } \\
\text { and } \\
\text { developed } \\
\text { countries) }\end{array}$ & $1975-1985$ & $\begin{array}{l}\text { GDP per capita; } \\
\text { education, defense, } \\
\text { and welfare } \\
\text { expenditures; } \\
\text { population }\end{array}$ & $\begin{array}{l}\text { Panel data } \\
\text { analysis }\end{array}$ & $\begin{array}{l}\text { Education and defense } \\
\text { expenditures have } \\
\text { positive effects while } \\
\text { welfare expenditures have } \\
\text { negative but insignificant } \\
\text { effect on growth }\end{array}$ \\
\hline $\begin{array}{c}\text { Barro } \\
(1991)\end{array}$ & $\begin{array}{c}98 \\
\text { (developing } \\
\text { and } \\
\text { developed } \\
\text { countries) }\end{array}$ & 1960-1985 & $\begin{array}{l}\text { Growth (in the real } \\
\text { GDP per capita); } \\
\text { human capital } \\
\text { (school-enrollment } \\
\text { rates); initial (1960) } \\
\text { level of real GDP per } \\
\text { capita. }\end{array}$ & $\begin{array}{c}\text { Panel data } \\
\text { analysis }\end{array}$ & $\begin{array}{l}\text { The growth rate is } \\
\text { positively related to initial } \\
\text { human capital and } \\
\text { negatively related to the } \\
\text { initial level of real GDP } \\
\text { per capita. Growth is } \\
\text { inversely related to the } \\
\text { government consumption, } \\
\text { but insignificantly related } \\
\text { to the public investment. }\end{array}$ \\
\hline $\begin{array}{l}\text { Devarajan, } \\
\text { Swaroop } \\
\text { and Zou } \\
\text { (1996) }\end{array}$ & $\begin{array}{c}43 \\
\text { (developing } \\
\text { countries) }\end{array}$ & $1970-1990$ & $\begin{array}{l}\text { GDP growth; public } \\
\text { expenditures in } \\
\text { education, health } \\
\text { defense, } \\
\text { transportation, and } \\
\text { communication }\end{array}$ & $\begin{array}{l}\text { Panel data } \\
\text { analysis and } \\
\text { OLS }\end{array}$ & $\begin{array}{c}\text { Education and defense } \\
\text { expenditures have } \\
\text { negative effects while } \\
\text { health, transportation, and } \\
\text { communication } \\
\text { expenditures have } \\
\text { contributions on the } \\
\text { growth. }\end{array}$ \\
\hline $\begin{array}{l}\text { Kelly } \\
\text { (1997) }\end{array}$ & $\begin{array}{c}73 \\
\text { (developing } \\
\text { and } \\
\text { developed } \\
\text { countries) }\end{array}$ & 1970-1989 & $\begin{array}{l}\text { GDP per capita; } \\
\text { public investment and } \\
\text { expenditures in } \\
\text { defense, education, } \\
\text { health, social security, } \\
\text { transportation, and } \\
\text { communication }\end{array}$ & $\begin{array}{l}\text { Panel data } \\
\text { analysis }\end{array}$ & $\begin{array}{l}\text { Public investment and } \\
\text { social expenditures } \\
\text { contribute to the growth. } \\
\text { Crowding - out and } \\
\text { rent - seeking concerns } \\
\text { seem to be overstated in } \\
\text { the literature. }\end{array}$ \\
\hline $\begin{array}{c}\text { Folster and } \\
\text { Henrekson } \\
(2001)\end{array}$ & $\begin{array}{c}23 \\
\text { (developed } \\
\text { OECD } \\
\text { countries }\end{array}$ & 1970-1995 & $\begin{array}{l}\text { GDP per capita; } \\
\text { human capital; labor } \\
\text { force growth rate; } \\
\text { investment rate; total } \\
\text { taxes as share of GDP }\end{array}$ & $\begin{array}{c}\text { Panel data } \\
\text { analysis, some } \\
\text { complementary } \\
\text { tests }\end{array}$ & $\begin{array}{l}\text { There is a strong negative } \\
\text { relationship between } \\
\text { social expenditures and } \\
\text { economic growth. }\end{array}$ \\
\hline $\begin{array}{l}\text { Baldacci, } \\
\text { Cui, } \\
\text { Clements, } \\
\text { and Gupta } \\
(2004) \\
\end{array}$ & $\begin{array}{c}120 \\
\text { (developing } \\
\text { countries) }\end{array}$ & $1975-2000$ & $\begin{array}{l}\text { Real GDP per capita; } \\
\text { social spending in } \\
\text { education, health; } \\
\text { population }\end{array}$ & $\begin{array}{l}\text { Panel data } \\
\text { analysis }\end{array}$ & $\begin{array}{l}\text { Both education and health } \\
\text { spending have positive } \\
\text { direct impacts on the } \\
\text { economic growth. }\end{array}$ \\
\hline $\begin{array}{l}\text { Dreger and } \\
\text { Reimers } \\
(2005)\end{array}$ & $\begin{array}{l}21 \mathrm{OECD} \\
\text { countries }\end{array}$ & $1975-2001$ & $\begin{array}{l}\text { GDP per capita; } \\
\text { Indices for health } \\
\text { expenditures }\end{array}$ & $\begin{array}{l}\text { Panel data } \\
\text { analysis }\end{array}$ & $\begin{array}{l}\text { Long-term positive } \\
\text { relationship between } \\
\text { health expenditures and } \\
\text { economic growth. }\end{array}$ \\
\hline $\begin{array}{l}\text { Beraldo, } \\
\text { Montolio } \\
\text { and Turati } \\
\text { (2009) }\end{array}$ & $\begin{array}{c}19 \\
\text { OECD } \\
\text { countries }\end{array}$ & 1971-1998 & $\begin{array}{l}\text { GDP per capita; } \\
\text { public and private } \\
\text { health expenditures; } \\
\text { public and private } \\
\text { education }\end{array}$ & $\begin{array}{l}\text { Panel data } \\
\text { analysis }\end{array}$ & $\begin{array}{l}\text { Health and education } \\
\text { expenditure contribute to } \\
\text { the growth. The impact of } \\
\text { health is stronger than } \\
\text { education. Public }\end{array}$ \\
\hline
\end{tabular}


expenditures

expenditures contribute to the GDP growth more than private expenditures.

\begin{tabular}{|c|c|c|c|c|c|}
\hline $\begin{array}{c}\text { Alam, } \\
\text { Sultana and } \\
\text { Butt (2010) }\end{array}$ & $\begin{array}{c}10 \\
\text { Asian } \\
\text { countries }\end{array}$ & $1970-2005$ & $\begin{array}{l}\text { GDP; education } \\
\text { health and social } \\
\text { security/welfare } \\
\text { expenditures }\end{array}$ & $\begin{array}{l}\text { Panel data } \\
\text { analysis }\end{array}$ & $\begin{array}{c}\text { Social expenditures } \\
\text { increase efficiency and } \\
\text { therefore, affect growth } \\
\text { positively. }\end{array}$ \\
\hline $\begin{array}{c}\text { Afonso and } \\
\text { Alegre } \\
(2011)\end{array}$ & $\begin{array}{l}15 \\
\text { European } \\
\text { Union } \\
\text { countries }\end{array}$ & 1971-2006 & $\begin{array}{l}\text { Growth (GDP per } \\
\text { capita); total factor } \\
\text { productivity; labor } \\
\text { productivity; } \\
\text { education, health, and } \\
\text { social expenditures }\end{array}$ & $\begin{array}{c}\text { Panel data } \\
\text { analysis }\end{array}$ & $\begin{array}{l}\text { Public expenditures } \\
\text { induce distortions in the } \\
\text { private factors allocation. } \\
\text { Public investment } \\
\text { enhances economic } \\
\text { growth by boosting } \\
\text { private investment } \\
\text { (crowding-in effect) }\end{array}$ \\
\hline $\begin{array}{l}\text { Carter, } \\
\text { Craigwell } \\
\text { and Lowe } \\
(2013)\end{array}$ & $\begin{array}{l}\text { Barbados } \\
\text { (a small } \\
\text { open } \\
\text { economy } \\
\text { case) }\end{array}$ & 1976-2011 & $\begin{array}{l}\text { GDP per capita; } \\
\text { health, education, and } \\
\text { social security } \\
\text { expenditures }\end{array}$ & $\begin{array}{l}\text { Dynamic OLS, } \\
\text { unrestricted error } \\
\text { correction model }\end{array}$ & $\begin{array}{c}\text { Total government } \\
\text { spending lessens growth } \\
\text { rates, particularly in the } \\
\text { short-run. Health and } \\
\text { social security } \\
\text { have little influences. } \\
\text { Education expenditures } \\
\text { have a negative impact on } \\
\text { growth, both in the } \\
\text { long and short runs. }\end{array}$ \\
\hline $\begin{array}{l}\text { Khan and } \\
\text { Bashar } \\
(2015)\end{array}$ & $\begin{array}{l}\text { Australia } \\
\text { and New } \\
\text { Zealand }\end{array}$ & 1980-2012 & $\begin{array}{l}\text { GDP per capita; } \\
\text { education, health, } \\
\text { social welfare } \\
\text { expenditures; budget } \\
\text { deficit }\end{array}$ & $\begin{array}{l}\text { Time series } \\
\text { analysis } \\
\text { (cointegration } \\
\text { and error } \\
\text { correction, } \\
\text { causality) }\end{array}$ & $\begin{array}{l}\text { Social expenditures } \\
\text { promote economic growth } \\
\text { in both countries. One } \\
\text { way causality running } \\
\text { from economic growth to } \\
\text { health and social } \\
\text { expenditures in Australia. } \\
\text { One-way causality runs } \\
\text { from education } \\
\text { expenditure to growth in } \\
\text { New Zealand }\end{array}$ \\
\hline
\end{tabular}

Both individual country-specific and country-aggregated studies in the huge literature generally conclude that the effects of government expenditures, presented by several measurements, on the growth that is commonly proxied by GDP per capita, vary over time and over countries. These unclear conclusions implicitly indicate that the conditions of contribution are country-specific. In this context, our study aims to contribute to the literature using a new dataset and different methods as outlined in the following section 4.

\section{Model, Data, and Method}

The theoretical model of the study associates a relationship between economic growth and governments' education, health, and social expenditures in selected 18 OECD countries as shown in equation 1.

$$
Y=f(E D U, H E A L T H, S O C I A L)
$$

Where, $Y$ is GDP per capita (constant 2005 USD), EDU is total public expenditures on education as a percentage of GDP, HEALTH is total public expenditure on health as a percentage of GDP and SOCIAL is the total public expenditures on social protection as the percentage of GDP. Social protection expenditure comprises cash benefits, direct in-kind provision of goods and services, and tax breaks by governments with social purposes (Adema et al., 2011; OECD, 2016). Expressing the variables in natural logarithms $(l n)$, the regression model in a panel structure is specified as in the equation 2 . 


$$
\begin{gathered}
\ln Y_{i t}=\beta_{0}+\beta_{1} \ln E D U_{i t}+\beta_{2} \ln \operatorname{HEALTH}_{i t}+\beta_{3} \ln S O C I A L_{i t}+\varepsilon_{i t} \\
(i=1, \ldots, 11 ; \quad t=2002, \ldots, 2013)
\end{gathered}
$$

In equation 2, all the variables are the same as previously defined and $i$ and $t$ stand for the cross-section units (countries) and temporal units (years), respectively, while $\beta_{0}$ is a country-specific intercept. The stochastic error term, $\varepsilon_{i t}$, comprises the influences of all other factors not included in the model. Finally, $\beta_{1}, \beta_{2}$ and $\beta_{3}$ are the elasticities to be estimated.

The study is based on annual dataset covering a period from 2002 to 2013 of 18 OECD countries including Austria, Belgium, Canada, Czech Republic, Germany, Denmark, Spain, Estonia, Finland, France, United Kingdom, Italy the Netherlands, Norway, Portugal, Sweden, the Unites States, and Turkey. The data of GDP per capita, total public expenditures on education and health are taken from the World Bank's World Development Indicator (WB-WDI, 2016) and expenditure on social protection is those of OECD (2016) and Eurostat (2016).

We followed the panel data analysis methodology as follows: First we checked cross-sectional dependence (CSD) using several tests like Pesaran's CD test, Friedman's test and Frees' test. Then, we controlled time series characteristics for heteroskedasticity, and autocorrelation through modified Wald test and Wooldridge test respectively. Finally, we estimate the coefficients using the feasible generalized least squares (FGLS) estimator.

\section{Empirical Results}

We checked time series characteristics for heteroskedasticity and autocorrelation problems using Pesaran, Friedman and Frees tests. Test statistics are presented in Table 4. Results indicate that there is a cross-sectional dependency between variables in all three tests.

Table 4. Cross-sectional dependence tests

\begin{tabular}{lcc}
\hline \multicolumn{1}{c}{ Tests } & Statistics & Probability $(p)$ values \\
\hline Pesaran's test & 18.701 & .000 \\
Friedman's test & 96.855 & .000 \\
Frees' test & 5.201 & Critical values from Q distribution are: \\
& & .214 (for .10) \\
& & .284 (for .05) \\
& & .425 (for .01) \\
\hline
\end{tabular}

Moreover, unreported statistics reveal that there are both heteroskedasticity and autocorrelation in the series. Therefore, we rearrange the calculations in FGLS procedure considering the case where cross-sectional dependency, heteroskedasticity and autocorrelation exist. The results of FGLS estimation are presented in Table 5.

Table 5. The results of FGLS estimation

\begin{tabular}{lccc}
\hline Independent variables & Coefficients & Standard errors & Probability $(p)$ values \\
\hline EDU & .065 & .002 & .000 \\
HEALTH & .052 & .001 & .000 \\
SOCIAL & .024 & .001 & .000 \\
CONSTANT & 9.024 & .040 & .000 \\
\hline
\end{tabular}

The coefficients reported in the Table 5 reveal that the effects of education, health and social protection expenditures on the economic growth are significantly positive. Education (.065) expenditures spent by the governments are found most contributing to the growth followed by the health (.052) and social protection (.024) expenditures. Again, high constant emphasizes the fact that a wide array of factors determines growth, besides government spending. 


\section{Conclusion}

There is a longstanding debate with no consensus on whether government expansion through public policies helps or hinders economic growth. Consistently, the empirical studies in the related literature conclude with unclear findings. Neoclassical growth theories predict a convergence between the growth paths of developing and developed countries. Since such convergence was not observed in the real world with a few exceptions from East Asia, the neoclassical growth model has been questioned by especially endogenous growth theories that highlight the importance of human capital. The endogenous growth theories, in general, predict that effective public expenditures can lead to increases in economic growth trends of countries regardless of their development stages or income levels.

Starting from this prediction, this study aims to investigate the effects of governments' social expenditures proxies like education, health and social protection on economic growth presented by the changes in gross domestic product per capita using a balanced panel dataset covering 2002-2013 periods of 18 OECD countries. Taking cross-sectional dependency, heteroskedasticity and autocorrelation into consideration, the study followed the feasible generalized least squares estimation procedure within the panel data framework.

Findings reveal that the effects of education, health and social protection expenditures on the economic growth are significantly positive. Education (.065) expenditures spent by the governments are found most contributing to the growth which followed by the health (.052) and social protection (.024) expenditures. Again, high constant emphasizes the fact that a wide array of factors determines growth, besides government spending. Supporting the predictions of endogenous growth theories in terms of the importance of human capital, overall results suggest that governments not only can eliminate the results of market failures by social spending directly but also, they can increase the welfare promoting the economic growth from various channels in the case of selected OECD countries.

\section{References}

Adema, W., Fron, P., \& Ladaique, M. (2011). Is the European welfare state really more expensive? Indicators on social spending, 1980-2012; and a manual to the OECD social expenditure database. OECD Social, Employment and Migration Working Papers, 124. http://dx.doi.org/10.1787/5kg2d2d4pbf0-en

Afonso, A., \& Juan, A. (2011). Economic growth and budgetary components: A panel assessment for the EU. Empirical Economics, 41(3), 703-723. http://dx.doi.org/10.1007/s00181-010-0400-9

Afzal, M., Farooq, M.S., Ahmad, H.K, Begum, I., \& Quddus, M.A. (2010). Relationship between school education and economic growth in Pakistan: ARDL bounds testing approach to cointegration. Pakistan Economic and Social Review, 48(1), 39-60.

Alam, S., Sultana, A., \& Butt, M.S. (2010). Does social expenditures promote economic growth? A multivariate panel cointegration analysis for Asian countries. European Journal of Social Sciences, 14(1), 44-54.

Arjona, R., Ladaique, M., \& Pearson, M. (2002). Social protection and growth, OECD Economic Studies, 35(2), 7-45. http://dx.doi.org/10.1787/eco_studies-v2002-art8-en

Baldacci, E., Clements, B., Gupta, S., \& Cui, Q. (2004). Social spending, human capital and growth in developing countries: Implications for achieving the MDGs. IMF Working Papers, WP/04/217, 1-40. http://dx.doi.org/10.5089/9781451875140.001

Barro, R.J. (1990). Government spending in a simple model of endogenous growth. The Journal of Political Economy, 98(5), 103-125. http://dx.doi.org/10.3386/w2588

Barro, R.J. (1991). Economic growth in a cross section of countries. The Quarterly Journal of Economics, 106(2), 407-443. http://dx.doi.org/10.2307/2937943

Barro, R.J. (2001). Human capital and growth. The American Economic Review, 91(2), 12-17. http://dx.doi.org/10.1257/aer.91.2.12

Barro, R.J. (2013). Education and economic growth. Annals of Economics and Finance, 14(2), 301-328.

Barro, R.J. (2013). Health and economic growth. Annals of Economics and Finance, 14(2), 329-366.

Bassanini, A., \& Scarpetta, S. (2002). Does human capital matter for growth in OECD countries? A pooled mean-group approach. OECD Economics Department Working Papers, 282. http://dx.doi.org/10.1787/424300244276

Baum, D.N., \& Lin, S. (1993). The differential effects on economic growth of government expenditures on education, welfare, and defense. Journal of Economic Development, 18(1), 175-185. 
Beraldo, S., Montolio, D., \& Turati, G. (2009). Healthy, educated and wealthy: A primer on the impact of public and private welfare expenditures on economic growth. The Journal of Socio-Economics, 38(1), 946-956. http://dx.doi.org/10.1016/j.socec.2009.06.013

Bloom, D.E., \& Canning, D. (2000). The health and wealth of nations. Science New Series, 287(5456), 1207-1209. http://dx.doi.org/10.1126/science.287.5456.1207

Carter, J., Craigwell, R., \& Lowe, S. (2013). Government expenditure and economic growth in a small open economy: A disaggregated approach. CBB Working Papers, WP/13/15. Retrieved from http://www.ccmf-uwi.org/files/publications/conference/2013/3_1-Carter_Craigwell_Lowe-p.pdf

Devarajan, S., Swaroop, V., \& Zou, H. (1996). The composition of public expenditure and economic growth. Journal of Monetary Economics, 37(2), 313-344. http://dx.doi.org/10.1016/S0304-3932(96)90039-2

Domar, E. (1946). Capital expansion, rate of growth, and employment. Econometrica, 14(1), 137-47. http://dx.doi.org/10.2307/1905364

Dreger, C., \& Reimers, H.E. (2005). Health care expenditures in OECD countries: A panel unit root and cointegration analysis. IZA Discussion Papers, 1469, 1-20. Retrieved from http://ftp.iza.org/dp1469.pdf

Eurostat. (2016). Retrieved from http://ec.europa.eu/eurostat/data/database

Folster, S., \& Henrekson, M. (2001). Growth effects of government expenditure and taxation in rich countries. European Economic Review, 45(8), 1501-1520.

Hausmann, R., Pritchett, L., \& Rodrik, D. (2005). Growth accelerations. Journal of Economic Growth, 10(4), 303-329. http://dx.doi.org/10.1007/s10887-005-4712-0

Kelly, T. (1997). Public expenditures and growth. The Journal of Development Studies, 34(1), 60-84. http://dx.doi.org/10.1080/00220389708422503

Khan, H., \& Bashar, O. (2015). Social expenditure and economic growth: evidence from Australia and New Zealand using cointegration and causality tests. The Journal of Developing Areas, 49(4), 285-300. http://dx.doi.org/10.1353/jda.2015.0137

Landau, D. (1983). Government expenditure and economic growth: A cross-country study. Southern Economic Journal, 49(3), 783-792. http://dx.doi.org/10.2307/1058716

Lucas, R.E. (1988). On the mechanics of economic development. Journal of Monetary Economics, 22(1), 3-42. http://dx.doi.org/10.1016/0304-3932(88)90168-7

Lustig, N. (2006). Investing in health for economic development: The case of Mexico. UNU-WIDER Research Papers, 2006/30. Retrieved from http://www.wider.unu.edu/sites/default/files/rp2006-30.pdf

Mankiw, N.G. (1995). The growth of nations. Brookings Papers on Economic Activity, 1995(1), 275-326. http://dx.doi.org/10.2307/2534576

OECD. (2016). OECD statistics. Retrieved from http://stats.oecd.org/

Pevcin, P. (2004). Does optimal size of government spending exist?. Retrieved from http://soc.kuleuven.be/io/egpa/fin/paper/slov2004/pevcin.pdf

Pyo, H.K. (1995). A time-series test of the endogenous growth model with human capital. Retrieved from http://www.nber.org/chapters/c8551.pdf

Rebelo, S.T. (1991). Long-run policy analysis and long-run growth. Journal of Political Economy, 99(3), 500-521. http://dx.doi.org/10.3386/w3325

Romer, P.M. (1986). Increasing returns and long run growth. Journal of Political Economy, 94(5), 1002-1037. http://dx.doi.org/10.1086/261420

Solow, R.M. (1956). Contribution to the theory of economic growth. The Quarterly Journal of Economics, 70(1), 65-94. http://dx.doi.org/10.2307/1884513

Stokey, N.L. (1991). Human capital, product quality and growth. Quarterly Journal of Economics, 106(2), 587-616. http://dx.doi.org/10.3386/w3413

WB-WDI. (2016). The World Bank, World Data Bank, World Development Indicators. Retrieved from http://databank.worldbank.org/data/reports.aspx?source=world-development-indicators 